\title{
A Novel Mouse Model for Type 2 Diabetes and Non-alcoholic Fatty Liver Disease: Spontaneous Amelioration of Diabetes by Augmented Beta Cell Mass
}

\author{
AYA OZE-FUKAI, TOMOMI FUJISAWA, KEN SUGIMOTO, KoJI NOJIMA, NOBUYASU SHINDO, \\ SATOMI SHIMOYOSHI, YUKI YOSHIKAWA, YOSHIFUMI SATO*, IICHIROU SHIMOMURA*, \\ HIROSHI IKEGAMI** AND HIROMI RAKUGI \\ Department of Geriatric Medicine, Osaka University Graduate School of Medicine, Suita, Japan \\ *Department of Metabolic Medicine, Osaka University Graduate School of Medicine, Suita, Japan \\ **Department of Endocrinology, Metabolism and Diabetes, Kinki University School of Medicine, Sayama, Japan
}

\begin{abstract}
Given the potential for $\beta$-cells to increase their mass, glucose intolerance might be ameliorated by a compensatory increase in $\beta$-cell mass. However, it remains uncertain whether such amelioration is feasible in vivo. In this study, we investigated glucose tolerance, islet morphology, and islet gene expression of Fatty Liver Shionogi (FLS) mice, a model for non-alcoholic fatty liver disease (NAFLD). Relative to control mice, FLS mice showed an age-dependent increase in glucose intolerance up to the age of 24 weeks, leading to the development of diabetes. After this time, glucose tolerance ameliorated spontaneously and diabetes resolved by 48 week of age, associated with marked hyperinsulinemia. Islets of the FLS mice demonstrated a marked increase in $\beta$-cell mass with an increase in $\beta$-cell numbers. Islet gene expression analysis in FLS mice demonstrated no changes in gene expression of glucokinase or insulin receptor substrate 2. These data demonstrated that the 24-week-old FLS mouse is a model for type 2 diabetes with NAFLD and that the 48week-old FLS mouse exhibits spontaneous amelioration of type 2 diabetes associated with augmented $\beta$-cell number/mass.
\end{abstract}

Key words: NAFLD, Type 2 diabetes mellitus, Islet, $\beta$-cell, FLS mouse

(Endocrine Journal 56: 227-234, 2009)

THE failure of pancreatic $\beta$-cells to produce sufficient insulin is pivotal to the development of type 2 diabetes mellitus. Total capacity of insulin secretion is largely dependent on the whole $\beta$-cell mass, which reflects the balance between $\beta$-cell increase and decrease [1]. Given the potential for $\beta$-cells to increase their mass, it is possible that glucose intolerance could be ameliorated. However, from a clinical perspective, after the de-

Received: October 31, 2008

Accepted: November 18, 2008

Correspondence to: Tomomi FUJISAWA, Department of Geriatric Medicine, Osaka University Graduate School of Medicine, 2-2, Yamdada-Oka, Suita-shi, Osaka 565-0871, Japan

Abbreviations: NAFLD, non-alcoholic fatty liver disease; FLS, Fatty Liver Shionogi; HOMA-R, homeostasis model assessment ratio; Gck, glucokinase; Ins2, insulin receptor substrate 2; LIRKO, liver-specific insulin receptor knockout velopment of the disease, insulin secretion generally declines [2], and it is widely accepted that the type 2 diabetes mellitus state is permanent and progressive [3].

Recently, several lines of genetically engineered animal models of type 2 diabetes [4-7] have demonstrated a possible compensatory augmentation in $\beta$-cell mass by suppression/activation of a specific biological pathway, suggesting the possible amelioration of type 2 diabetes. However, such spontaneous amelioration is not common, especially in humans. Therefore, an in vivo model of glucose intolerance amelioration without intervention is needed.

Fatty Liver Shionogi (FLS) mice [8] are an inbred line established as a model for spontaneous severe non-alcoholic fatty liver disease (NAFLD) [9]. Since the NAFLD is strongly associated with insulin resistance as well as with diabetes mellitus [10], FLS mice 
may exhibit abnormal glucose tolerance.

In this study, we investigated glucose tolerance of FLS mice longitudinally and assessed any associated changes in $\beta$-cell mass. To evaluate mechanisms of compensatory increases in $\beta$-cell mass, we studied islet expression of two genes known to be involved in islet hypertrophy.

\section{Materials and Methods}

\section{Animals}

FLS mice were obtained from Aburahi Laboratories, Shionogi, Inc. (Shiga, Japan). C57BL/6 mice were purchased from Charles River, Inc. (Japan). Both strains of mice were maintained in the animal facilities of Osaka University Medical School in an air-conditioned room $\left(22-25^{\circ} \mathrm{C}\right)$ with a 12-h light/dark cycle and were given free access to food (standard chow) and water, according to the Osaka University Medical School Guidelines for the Care and Use of Laboratory Animals.

\section{Phenotype determination}

Plasma lipoprotein levels were analyzed by a dual enzymatic method for simultaneous quantification of cholesterol and triglycerides by high-performance liquid chromatography at Skylight Biotech (Akita, Japan), according to the procedure described by Okazaki et al. [11]. Blood glucose level (mg/dl) was measured by the glucose oxidase method using Glutest E (Kyoto Daiichi Kagaku, Kyoto, Japan). Glucose tolerance analysis was performed by intraperitoneal glucose tolerance test (ipGTT; $2 \mathrm{~g}$ glucose/kg body wt) after overnight fasting at $8,16,24,32,40$, and 48 weeks of age. Blood glucose concentrations were measured at fasting ( $0 \mathrm{~min}$ ), and $30,60,90$, and $120 \mathrm{~min}$ post glucose load. Diabetes was diagnosed if the glucose level exceeded $200 \mathrm{mg} / \mathrm{dl}$ at $120 \mathrm{~min}$ after the glucose load. To assess the insulin secretion in response to glucose, plasma insulin concentrations were measured at fasting and at 15 and 30 minutes after intraperitoneal glucose administration $(2 \mathrm{~g} / \mathrm{kg}$ body $\mathrm{wt})$ at 24 and 48 weeks of age. Plasma insulin concentration was measured using an insulin enzyme-linked immunosorbent assay kit (Morinaga Seikagaku, Yokohama, Japan). To assess insulin resistance, the homeostasis model assessment ratio (HOMA-R) was calculated by the following equation: HOMA-R $=$ Fasting glucose $(\mathrm{mg} / \mathrm{dl}) \times$ Fasting insulin $(\mathrm{pg} / \mathrm{ml}) / 405$. BMI was calculated as body weight $(\mathrm{g})$ divided by the square of anal-nasal distance $(\mathrm{cm})$. All animals were killed under anaesthesia by intraperitoneal administration of pentobarbital at 24 and 48 weeks of age.

\section{Histological examination of pancreas}

Paraffin sections of the pancreas were stained with hematoxylin/eosin by the standard method. Five pancreatic sections from each animal were analyzed. Quantification of islet mass for each sample was performed using a BZ-Analyzer (Keyence, Osaka, Japan). Numbers of islets per one section, numbers of $\beta$-cells per one islet, and fractional $\beta$-cell area of the pancreas was calculated using the BZ-Analyzer. The cell size was calculated by dividing the $\beta$-cell area by the number of $\beta$-cell nuclei.

\section{$m R N A$ expression analysis}

Pancreatic islets were isolated from four or five male 32-week-old FLS or C57BL/6 mice per experiment by a collagenase digestion method [12]. Total RNA was extracted from frozen islets using the QIAGEN microRNeasy Mini Kit and cDNA was synthesized using ReverTra Ace $\alpha$ (TOYOBO, Tokyo, Japan). Quantitative RT-PCR was performed using Taqman-PCR method (ABI). We evaluated expression of the following two genes; Gck for glucokinase and $\operatorname{Irs} 2$ for insulin receptor substrate 2; these molecules have been implicated in $\beta$-cell expansion [13]. $\mathrm{ABI}$ inventoried TaqMan ${ }^{\circledR}$ gene expression assays are as follows: Gene name/ABI ID: Gck/Mm00439129 $\mathrm{m} 1$; Irs2/Mm03038438_m1. The PCR reactions for TaqMan $^{\circledR}$ gene expression assays contained $1.0 \mu \mathrm{l}$ cDNA, $10 \mu \mathrm{l}$ Master Mix, and $1.0 \mu \mathrm{l}$ primer probe mixture, made up to a final volume of $20 \mu \mathrm{l}$ with sterile water. All experiments were performed in duplicate using an ABI 7900 HT Fast real-time PCR System (Applied Biosystems, Darmstadt, Germany). The real-time RT-PCR protocol was as follows: Denaturation by a hot start at $95^{\circ} \mathrm{C}$ for $10 \mathrm{~min}$, followed by 40 cycles of the two-step program: denaturation at $95^{\circ} \mathrm{C}$ for $15 \mathrm{sec}$ and annealing/extension at $60^{\circ} \mathrm{C}$ for $1 \mathrm{~min}$. Gene expression (E) was normalized to Actb expression (ABI ID; Mm00607939_s1). 


\section{Statistical analysis}

All results are expressed as the mean \pm standard error. Phenotypic data were analyzed either by Student's t test or one-way analysis of variance with post hoc analysis using Scheme's F test. Differences with $p<0.05$ were regarded as significant. All statistical analyses were performed using StatView version 5.0 software (SAS Institute, Cary, NC).

\section{Results}

\section{Physiologic and biochemical characteristics}

There were no differences in food or water intake or BMI between the FLS and C57BL/6 mice at 32 weeks of age (Table 1). Neither was there any difference in subcutaneous fat weight between the two lines. However, body and liver weights of the FLS mice were significantly greater than those of the C57BL/6 mice ( $p=0.002$ and $p<0.0001$, respectively). Serum total cholesterol and triglyceride levels were significantly higher in the FLS mice than the C57BL/6 mice $(p<0.01$ and $p<0.05$, respectively). As the liver function may influence glucose tolerance, we investigated transaminase levels. At 24 weeks of age, the serum alanine aminotransferase level $(39.6 \pm 9.7$ vs. $20 \pm 4.3$ $\mathrm{IU} / \mathrm{L}$, respectively; $p=0.03$ ) and the aspartate aminotransferase level $(175.3 \pm 15.9$ vs. $94.3 \pm 11.5 \mathrm{IU} / \mathrm{L}$, respectively; $p=0.002$ ), of the FLS mice were significantly higher than that of control mice. At 48 weeks of age, the serum alanine aminotransferase level $(24.8 \pm 13.0$ vs. $3.3 \pm 1.4 \mathrm{IU} / \mathrm{L}$, respectively; $p<0.001)$, but not the aspartate aminotransferase level $(p=0.06)$, of the FLS mice was significantly higher than that of control mice (Table 1).

\section{Glucose tolerance}

Glucose tolerance was assessed longitudinally by ipGTT. From 8 through 24 weeks of age, the glucose tolerance of the FLS mice became progressively impaired (Fig. 1). In FLS mice, the glucose level at $120 \mathrm{~min}$ exceeded $200 \mathrm{mg} / \mathrm{dl}$ at the age of 16 weeks and peaked at $290 \mathrm{mg} / \mathrm{dl}$ at the age of 24 weeks. Interestingly, the glucose levels of the FLS mice decreased with age beginning at 24 weeks to 48 weeks of age. At 48 weeks of age, the 120-min glucose level was below $200 \mathrm{mg} / \mathrm{dl}$, indicating that the glucose tolerance of the FLS mice ameliorated spontaneously.

\section{Insulin secretion and resistance}

At 24 weeks of age, the serum insulin level in the FLS mice was significantly higher at baseline $(p<0.001)$, at $15 \mathrm{~min}(p<0.001)$, and $30 \mathrm{~min}(p<0.001)$ post glucose load than in control mice (Fig. 2). At the age of 48 weeks, the insulin levels of FLS mice were much higher than those of the control mice $(p<0.001$ at baseline, $p<0.05$ at $15 \mathrm{~min}, p<0.05$ at $30 \mathrm{~min}$ ). Furthermore, the baseline insulin level at 48 weeks of age of FLS mice was much higher than that at 24 weeks of age of FLS mice $(p<0.001)$ (Fig. 2).

Table 1. Food and water intake, BMI, tissue weights, liver enzyme levels, and serum lipid levels in FLS and C57BL/6 mice.

\begin{tabular}{|c|c|c|c|}
\hline & $\mathrm{C} 57 \mathrm{BL} / 6$ & FLS & $p$-value \\
\hline Food intake $(\mathrm{mg} / \text { day/g BW })^{\mathrm{a}}$ & $0.069 \pm 0.024$ & $0.088 \pm 0.002$ & ns \\
\hline Water intake (mg/day/g BW $)^{\mathrm{a}}$ & $0.142 \pm 0.009$ & $0.149 \pm 0.030$ & ns \\
\hline Body weight $(\mathrm{g})^{\mathrm{b}}$ & $33.13 \pm 4.51$ & $40.37 \pm 3.20$ & 0.002 \\
\hline BMI $\left(\mathrm{g} / \mathrm{cm}^{2}\right)^{\mathrm{b}}$ & $0.441 \pm 0.022$ & $0.445 \pm 0.018$ & ns \\
\hline \multicolumn{4}{|l|}{ Tissue weights $(\mathrm{mg})^{\mathrm{b}}$} \\
\hline Liver & $1540 \pm 215$ & $2303 \pm 546$ & $<0.0001$ \\
\hline Pancreas & $327 \pm 60$ & $292 \pm 16$ & ns \\
\hline Visceral fat & $1062 \pm 504$ & $1229 \pm 714$ & $\mathrm{~ns}$ \\
\hline \multicolumn{4}{|l|}{ Liver enzyme level $^{\mathrm{b}}$ (IU/L) } \\
\hline Aspartate aminotransferase & $70.57 \pm 31.98$ & $129.40 \pm 66.74$ & 0.06 \\
\hline Alanine aminotransferase & $3.29 \pm 1.38$ & $24.80 \pm 12.95$ & 0.001 \\
\hline \multicolumn{4}{|l|}{ Serum lipid level ${ }^{\mathrm{b}}(\mathrm{mg} / \mathrm{dl})$} \\
\hline Total cholesterol & $91.5 \pm 9.14$ & $118.6 \pm 20.3$ & 0.01 \\
\hline Triglycerides & $68.5 \pm 24.6$ & $123.7 \pm 44.8$ & 0.02 \\
\hline
\end{tabular}



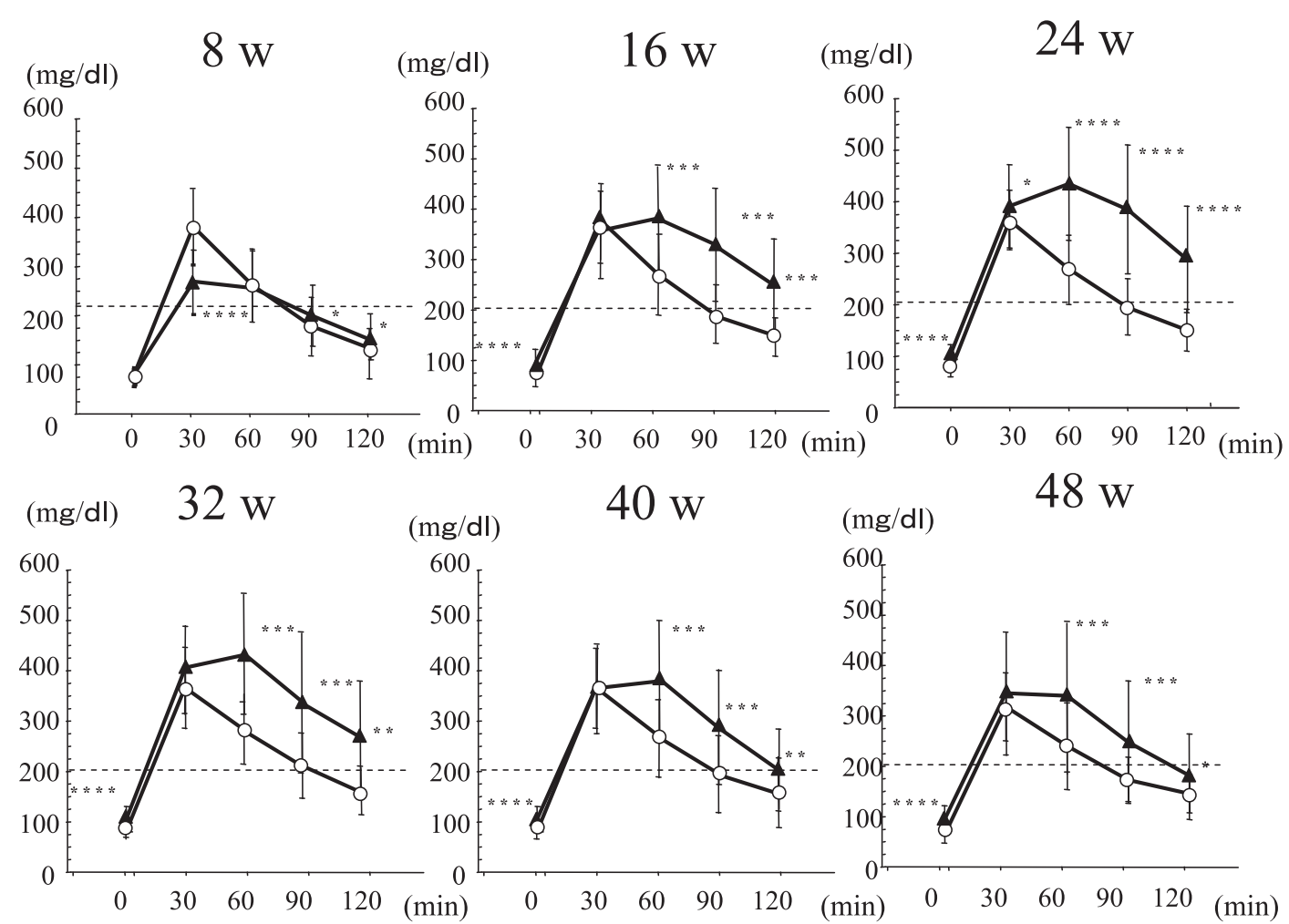

Fig. 1. Glucose tolerance in C57BL6 mice (white circle) and FLS mice (black triangle up) between 8 and 48 weeks of age. Data are expressed as means \pm standard errors. $* p<0.05 ; * p<0.01 ; * * * p<0.005 ; * * * *<0.001$ vs. C57BL6.

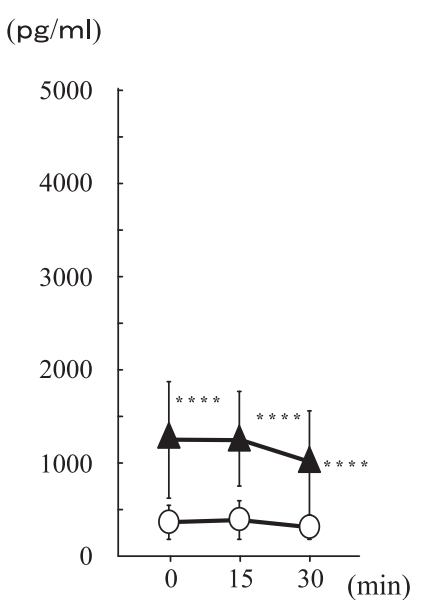

$24 \mathrm{w}$

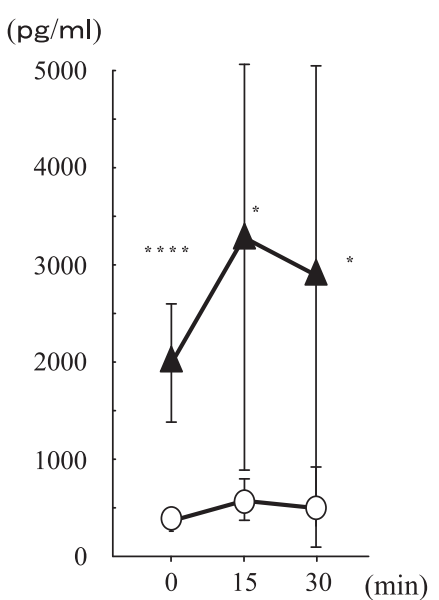

$48 \mathrm{w}$

Fig. 2. Insulin concentration during oral glucose tolerance tests in C57BL6 mice (white circle) and FLS mice (black triangle up) at 24 and 48 weeks of age. Data are expressed as means \pm standard errors. $* p<0.05 ; * * p<0.01 ; * * * p<0.005 ; * * * * p<0.001$ vs. C57BL6.

The HOMA-R of the FLS mice was significantly higher than that of the $\mathrm{C} 57 \mathrm{BL} / 6$ mice at 24 and 48 weeks of age $(p<0.001$ and $p<0.005$, respectively) (Fig. 3). The HOMA-R of the FLS mice at 48 weeks was much higher than that of FLS mice at 24 weeks of age, indicating an age-dependent deterioration in insulin sensitivity. 


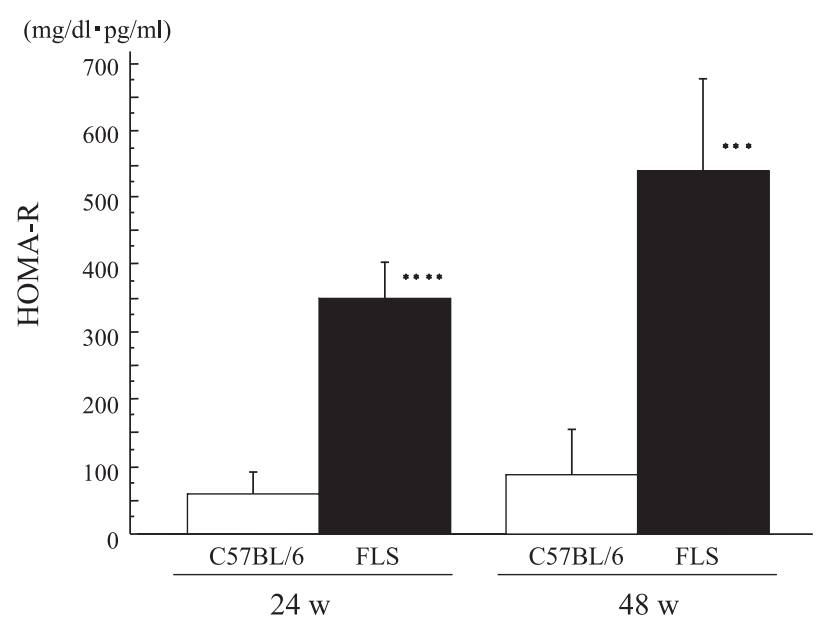

Fig. 3. HOMA-R in C57BL6 mice (white bar) and FLS mice (black bar) at 24 and 48 weeks of age. Data are expressed as means \pm standard errors. $* * * p<0.005$; $* * * * p<0.001$ vs. C57BL6.

\section{Islet morphology}

In control mice, there were no differences in the islet size and the number of $\beta$-cells at 24 weeks and 48 weeks of age (Fig. 4). In contrast, islet size and the number of $\beta$-cells in FLS mice were markedly greater at 48 weeks than at 24 weeks of age. At 48 weeks of age, islet size, islet number, and relative islet area (islet area/whole pancreas area), but not the size of the $\beta$ - cells, of the FLS mice were significantly greater than those of the C57BL/6 mice (Fig. 5), suggesting that islet augmentation was due to an increase in number of $\beta$-cells as opposed to $\beta$-cell hypertrophy.

\section{Islet gene expression analysis}

To investigate the mechanism of $\beta$-cell mass augmentation in FLS mice, we examined islet expression of two genes reportedly required for $\beta$-cell hyperplasia. There were no differences in the expression of Irs2 and Gck between FLS and control mice (Fig. 6).

\section{Discussion}

We found that glucose tolerance of FLS mice deteriorated continuously up to 24 weeks of age, after which time glucose tolerance ameliorated spontaneously. By 48 weeks of age, the glucose intolerance of these mice improved with hyperinsulinemia. Morphological analysis of the pancreas revealed marked augmentation of the $\beta$-cell mass with an increase in $\beta$-cell number in FLS mice. Thus, the 48-week-old FLS mouse is a model for spontaneous amelioration of type 2 diabetes by compensatory augmentation of $\beta$-cell number/ mass.

\section{$\mathrm{C} 57 \mathrm{BL} / 6$}
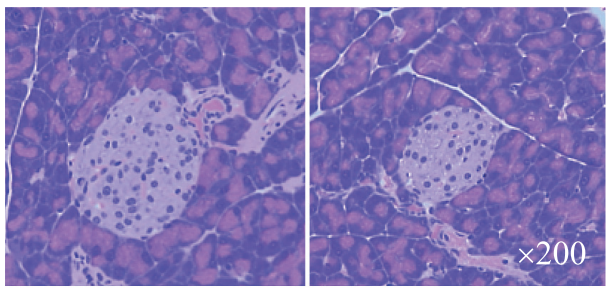

FLS
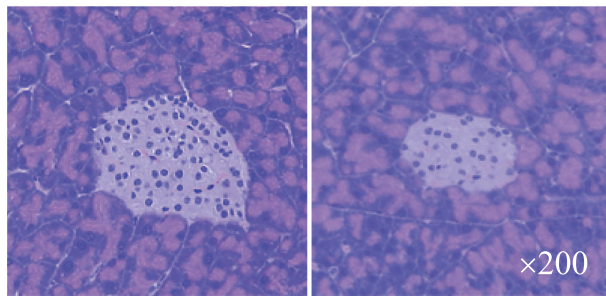

\section{$48 w$}
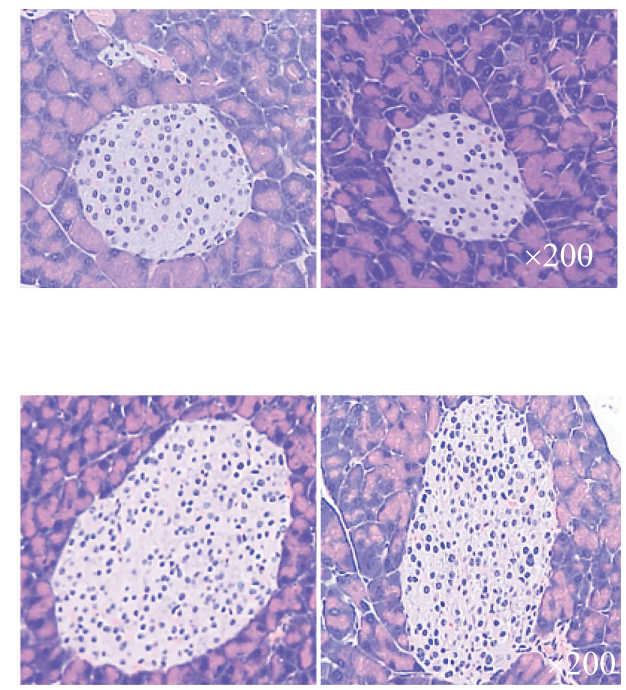

Fig. 4. Histological analysis of pancreatic islets from C57BL/6 and FLS mice at 24 weeks and 48 weeks of age. Sections were stained with hematoxylin/eosin. 

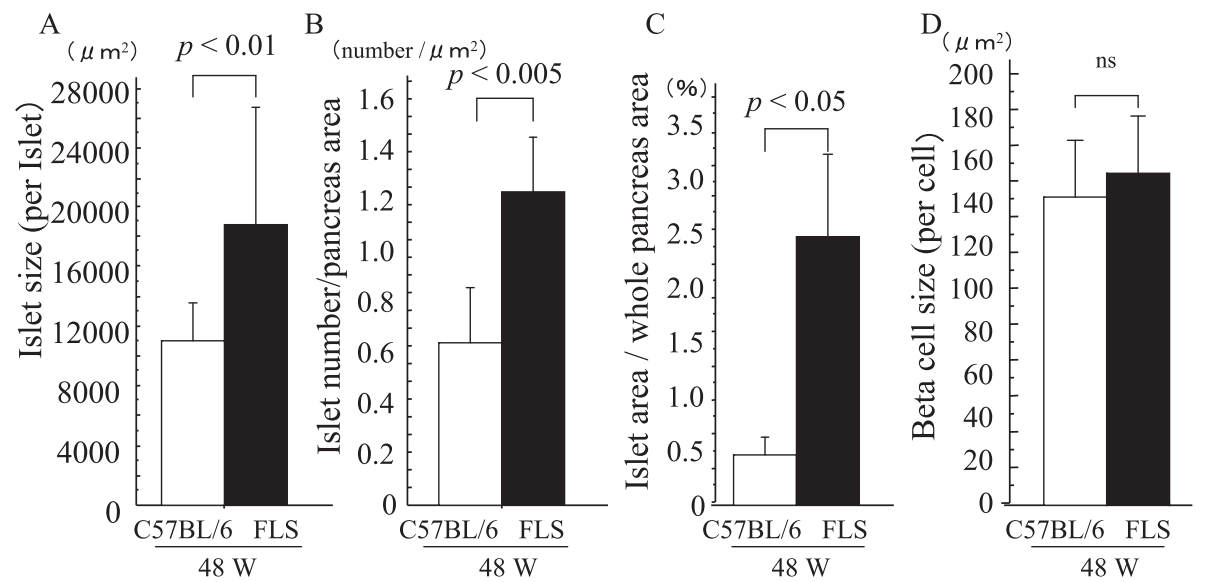

Fig. 5. Quantification of islet and beta cell mass in C57BL6 mice (white bar) and FLS mice (black bar) at 48 weeks of age. (A) Islet size (per islet); (B) islet numbers (per $\mu \mathrm{m}^{2}$ ); (C) areas of islets relative to the total area of the pancreas; (D) beta cell size.
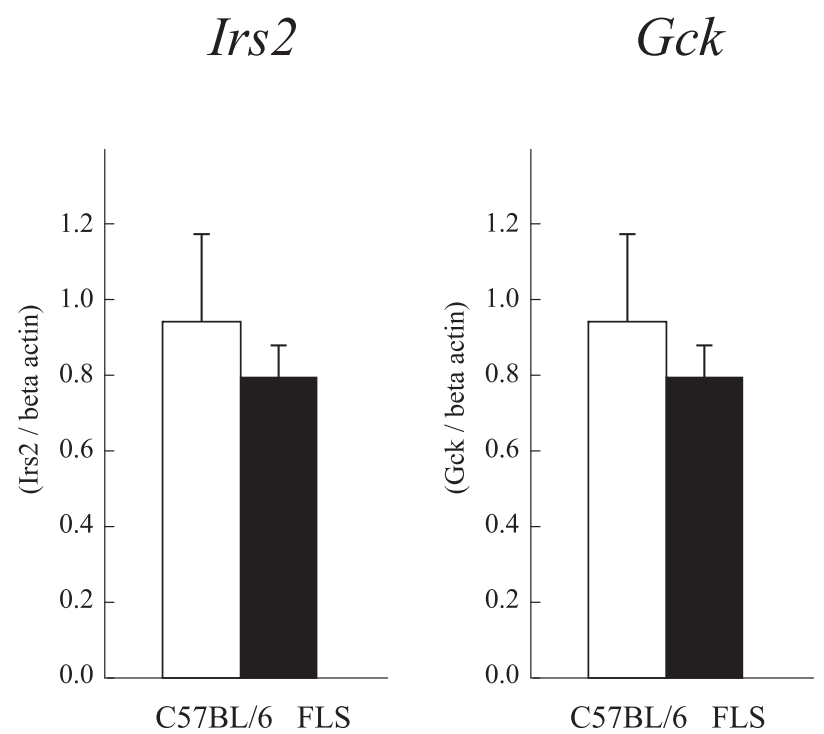

Fig. 6. Gene expression levels of Irs 2 and Gck in islets of C57BL6 mice and FLS mice at 32 weeks of age. The expression levels of Irs 2 and Gck were examined by real-time PCR their relative mRNA expression levels were determined (normalized to Actb expression). C57BL6 mice, white bar; FLS mice, black bar. Data are expressed as means \pm standard errors. $* p<0.05$ vs. C57BL6.

There is a growing interest in the relationship between NAFLD and type 2 diabetes. In our study, glucose tolerance of FLS mice at 16 weeks of age was impaired and the mice developed diabetes mellitus (Fig. 1). Furthermore, the FLS mice had insulin resistance at 24 weeks of age. These data indicate that the 24-week-old FLS mouse is an inbred model for the spontaneous development of type 2 diabetes with insulin resistance and NAFLD.

One of the important findings of this study is that in the absence of any specific intervention, the glucose tolerance of FLS mice improved after 24 weeks of age (Fig. 1). These mice did display marked hyperinsulinemia (Fig. 2) and an augmented $\beta$-cell number/ mass (Fig. 4). Thus, the 48-week-old FLS mouse is an in vivo model for spontaneous amelioration of type 2 diabetes mellitus. The most important point in FLS mice is the time lag in the occurrence between insulin resistance and compensatory beta cell hyperplasia. In humans, it has been questioned whether $\beta$-cell dysfunction is reversible, as clinical lines of evidence support a continuous decline in acquired $\beta$-cell function and/or decreased $\beta$-cell mass $[2,14]$. However, as shown in our study, spontaneous amelioration of diabetes is feasible in a mouse model, pointing to the possible amelioration of type 2 diabetes in a subset of patients. A key to the amelioration is the $\beta$-cell capacity for compensatory mass augmentation ( $\beta$-cell factor) and the conditions permitting this augmentation (non- $\beta$-cell factors). It is also possible that improved insulin secretion in response to glucose is responsible for the spontaneous amelioration of diabetes in this model. To clarify this possibility, static incubation study with FLS islets is warranted.

The liver-specific insulin receptor knockout (LIRKO) mouse was reported to have elevated serum glucose at 24 weeks of age, but the glucose level decreased at 48 weeks, with islet hyperplasia at 10 months of age [7]. The time course of alterations in glucose metabo- 
lism of the LIRKO mouse resembles that of the FLS mouse. The common phenotypes between the two models are mild hyperglycemia with hyperinsulinemia and hepatic resistance to insulin. Because glucose itself is known to mediate the adaptive increase in $\beta$-cell mass to metabolic demands $[15,16]$, mild to moderate hyperglycaemia after 16 weeks of age in the FLS mouse would have contributed to the adaptive $\beta$-cell mass augmentation as a non- $\beta$-cell factor.

Several genetically-engineered mouse models have indicated the importance of insulin signalling within $\beta$-cells [7] in the control of $\beta$-cell mass, especially insulin receptor substrate 2 [13]. We found that Irs2 expression was no higher in FLS islets than in control islets (Fig. 6). However, the excessive serum insulin level of the FLS mouse (5.4-fold greater than in control mice) indicates extremely abundant insulin within the islets, the sole source of insulin. Thus, it is likely that the excess insulin within the islets would stimulate insulin signalling in $\beta$-cells in an autocrine/paracrine manner, thereby contributing to the observed compensatory augmentation of $\beta$-cell mass. Thus, a sufficient amount of insulin outside the $\beta$-cells (a non- $\beta$-cell factor) and non-impaired insulin signalling within the $\beta$-cells (a $\beta$-cell factor) are required for $\beta$-cell augmentation.

Glucokinase acts as a sensor of the glucose level of $\beta$-cells and was shown to be required for $\beta$-cell hyperplasia in response to insulin resistance [13]. In the present study, islet expression of Gck was not increased in FLS mice, indicating that alternate signalling pathways ( $\beta$-cell factors) are involved in islet expansion. Therefore, FLS islets represent a unique source for identifying a $\beta$-cell factor necessary for sufficient augmentation of $\beta$-cell mass.

As shown in the Fig. 1, the glucose levels at $30 \mathrm{~min}$ during ipGTT were similar between the FLS mice and the C57BL/6, at various weeks of age. We interpreted this observation to mean that the absorption of intraperitoneally-administered glucose to serum is greater than the clearance of the glucose, both in FLS and the C57BL/6 mice, resulting in the similar glucose levels at $30 \mathrm{~min}$ during ipGTT. In contrast, glucose levels before a glucose load showed a significant difference from 16 weeks through 48 weeks of age. For example, at 24 weeks of age, the fasting glucose level of the FLS mice was significantly higher than that of control $(108 \pm 19$ vs. $78 \pm 12 \mathrm{mg} / \mathrm{dl}, p<0.001)$.

To further assess the underlying mechanism for the beta cell mass augmentation in this model, further analysis of proliferation (e.g. BrdU, Ki67) and apoptosis (Tunnel, FasL) of beta cells as well as of the expression levels of cell cycle regulators, such as p27Kip1 or Menin, will be required. It is also possible that the spontaneous amelioration of diabetes in this model would involve changes in glucagon secretion as well as in alpha-cell mass, reported to affect glucose tolerance [17]. Future analyses of the glucagon levels and alpha-cell mass of the FLS mice are required to assess this possibility.

In summary, our results indicate that the 24-weekold FLS mouse is a model for type 2 diabetes with NAFLD and that the 48-week-old FLS mouse exhibits spontaneous amelioration of type 2 diabetes associated with augmented $\beta$-cell number/mass. This model is useful to clarify the biological relationship between NAFLD and diabetes as well as the factors responsible for insufficient augmentation of $\beta$-cell mass in diabetes.

\section{Acknowledgements}

We wish to thank Ms. Y. Tsukamoto, M. Moritani, Y. Yoshizaki, and M. Iwanaga for their skilful technical assistance, and Dr. T. Hirasawa (Shionogi \& Co., Ltd.) for the gift of FLS mice. This study was supported by a Grant-in-Aid for Scientific Research (C) from the Japan Society for the Promotion of Science, Japan.

\section{References}

1. Rhodes CJ (2005) Type 2 diabetes-a matter of beta-cell life and death? Science 307: 380-384.

2. Meier JJ, Butler AE, Saisho Y, Monchamp T, Galasso R, Bhushan A, Rizza RA, Butler PC (2008) Beta-cell replication is the primary mechanism subserving the postnatal expansion of beta-cell mass in humans.
Diabetes 57: 1584-1594.

3. Bagust A, Beale S (2003) Deteriorating beta-cell function in type 2 diabetes: a long-term model. Qjm 96: 281-288.

4. Oyama K, Minami K, Ishizaki K, Fuse M, Miki T, Seino S (2006) Spontaneous recovery from hyper- 
glycemia by regeneration of pancreatic beta-cells in Kir6.2G132S transgenic mice. Diabetes 55: 19301938.

5. Rachdi L, Balcazar N, Osorio-Duque F, Elghazi L, Weiss A, Gould A, Chang-Chen KJ, Gambello MJ, Bernal-Mizrachi E (2008) Disruption of Tsc2 in pancreatic beta cells induces beta cell mass expansion and improved glucose tolerance in a TORC1-dependent manner. Proc Natl Acad Sci USA 105: 9250-9255.

6. Zhong L, Georgia S, Tschen SI, Nakayama K, Nakayama K, Bhushan A (2007) Essential role of Skp2-mediated p27 degradation in growth and adaptive expansion of pancreatic beta cells. J Clin Invest 117 : 2869-2876.

7. Okada T, Liew CW, Hu J, Hinault C, Michael MD, Krtzfeldt J, Yin C, Holzenberger M, Stoffel M, Kulkarni RN (2007) Insulin receptors in beta-cells are critical for islet compensatory growth response to insulin resistance. Proc Natl Acad Sci USA 104: 89778982.

8. Soga M, Kishimoto Y, kawaguchi J, Nakai Y, Kawamura Y, Inagaki S, Katoh K, Oohara T, Makino S, Oshima I (1999) The FLS mouse: a new inbred strain with spontaneous fatty liver. Lab Anim Sci 49: 269-275.

9. Harano $\mathrm{Y}$, Yasui $\mathrm{K}$, Toyama $\mathrm{T}$, Nakajima $\mathrm{T}$, Mitsuyoshi H, Mimani M, Hirasawa T, Itoh Y, Okanoue T (2006) Fenofibrate, a peroxisome proliferator-activated receptor alpha agonist, reduces hepatic steatosis and lipid peroxidation in fatty liver Shionogi mice with hereditary fatty liver. Liver International 26: 613-620.

10. Utzschneider KM, Kahn SE (2006) Review: The role of insulin resistance in nonalcoholic fatty liver disease. J Clin Endocrinol Metab 91: 4753-4761.

11. Okazaki M, Usui S, Ishigami M, Sakai N, Nakamura T, Matsuzawa Y, Yamashita S (2005) Identification of unique lipoprotein subclasses for visceral obesity by component analysis of cholesterol profile in highperformance liquid chromatography. Arterioscler Thromb Vasc Biol 25: 578-584.

12. Kulkarni RN, Wang ZL, Wang RM, Hurley JD, Smith DM, Ghatei MA, Withers DJ, Gardiner JV, Bailey CJ, Bloom SR (1997) Leptin rapidly suppresses insulin release from insulinoma cells, rat and human islets and, in vivo, in mice. J Clin Invest 100: 2729-2736.

13. Terauchi Y, Takamoto I, Kubota N, Matsui J, Suzuki R, Komeda K, Hara A, Toyoda Y, Miwa I, Aizawa S, Tsutsumi S, Tsubamoto Y, Hashimoto S, Eto K, Nakamura A, Noda M, Tobe K, Aburatani H, Nagai R, Kadowaki T (2007) Glucokinase and IRS-2 are required for compensatory beta cell hyperplasia in response to high-fat diet-induced insulin resistance. $J$ Clin Invest 117: 246-257.

14. Festa A, Williams K, D'Agostino R, Wagenknecht LE, Haffner SM (2006) The natural course of beta-cell function in nondiabetic and diabetic individuals: the Insulin Resistance Atherosclerosis Study. Diabetes 55: 1114-1120.

15. Paris M, Bernard-Kargar C, Berthault MF, Bouwens L, Ktorza A (2003) Specific and combined effects of insulin and glucose on functional pancreatic beta-cell mass in vivo in adult rats. Endocrinology 144: 2717-2727.

16. Bonner-Weir S, Deery D, Leahy JL, Weir GC (1989) Compensatory growth of pancreatic beta-cells in adult rats after short-term glucose infusion. Diabetes 38: 4953.

17. Cantley J, Choudhury AI, Asare-Anane H, Selman C, Lingard S, Heffron H, Herrera P, Persaud SJ, Withers DJ (2007) Pancreatic deletion of insulin receptor substrate 2 reduces beta and alpha cell mass and impairs glucose homeostasis in mice, Diabetologia 50: 1248 1256. 